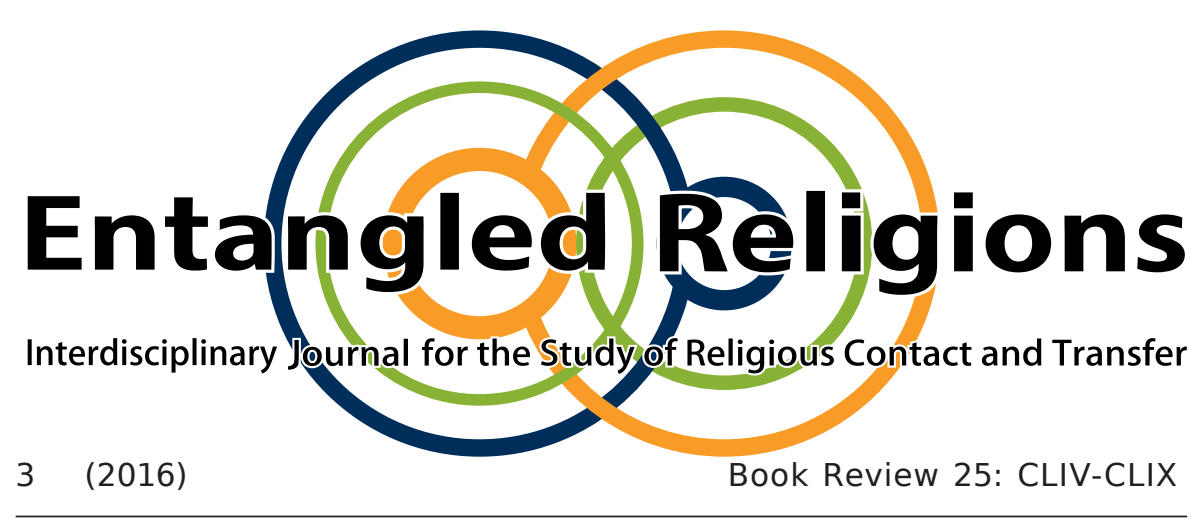

George Orwell and Religion

Bloomsbury Academic: London/Oxford/New York/

New Delhi/Sydney, 2016. 208 pages, \$94.00/£70.00, ISBN (hardback) 9781472531940

MICHAEL G. BRENNAN

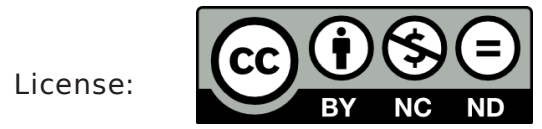

This contribution to Entangled Religions is published under the Creative Commons Attribution-NonCommercial-NoDerivatives 4.0 International Public License (CC BY-NC-ND 4.0 International). The license can be accessed at http://creativecommons.org/licenses/ by-nc-nd/4.0/ or is available from Creative Commons, 559 Nathan Abbot Way, Stanford, California 94305, USA.

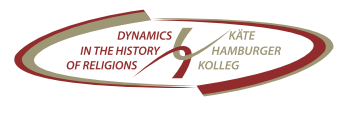

SPONSORED BY THE 


\title{
George Orwell and Religion
}

\author{
Bloomsbury Academic: London/Oxford/New \\ York/New Delhi/Sydney, 2016. 208 pages, \\ $\$ 94.00 / £ 70.00$, ISBN (hardback) 9781472531940
}

MICHAEL G. BRENNAN

\author{
A happy vicar I might have been \\ Two hundred years ago \\ To preach upon eternal doom \\ And watch my walnuts grow \\ George Orwell (1935)
}

Do we need another book on Orwell? Michael Brennan's take is certainly one that most authors have not concerned themselves with. George Woodcock considered that Orwell had his say about religion in A Clergyman's Daughter and then moved on, whilst retaining a detestation of bishops, Nonconformist preachers and Catholic intellectuals throughout his life. Bernard Crick's standard work pays some attention to Orwell's youthful interest in, and rejection of, formal religious observance and then to the Clergyman's Daughter. Most writers pass over the religion and get straight into the central political themes in Orwell's writing. Michael Brennan has therefore done students of Orwell-of whom there are a very large number-a service by tracing what the writer had to say about religion

1 From a poem first published in Orwell's essay 'Why I Write' (1946). https://www. theorwellprize.co.uk/the-orwell-prize/orwell/essays-and-other-works/why-i-write/ (last accessed 22 November, 2016). 
throughout his all too short career, and by locating it in the context of his family background, his education and his literary life. The central theme of Brennan's book is Orwell's enduring antipathy for the Catholic Church and Catholic intellectuals (as ever with Orwell, in principle but not usually when it came to individuals), the Protestant roots of his humanitarian individualism and his continuing awareness of a God-shaped hole in his engagement with the human condition. Brennan reminds us of the ways in which Orwell's political thinking, and especially his portrayal of totalitarianism, had roots in his conception of religious organisations.

Of course none of Orwell's biographers, critics and apologists can overlook his spirituality and his fear that, in the absence of the mild old faith of the English Church, there was a danger that its place would be taken by harsh totalitarian doctrines. The widespread view of Orwell as a saintly figure, with an austere personal life and an uncompromising commitment to integrity was established by authors who had known Orwell soon after his death such as V S Pritchett, Anthony Powell and Malcom Muggeridge, but there was never any suggestion that he was a believer.

Brennan touches only by way of introduction on this saintliness of Orwell. The book is largely a chronological survey of what Orwell had to say about religions and the religious. This amounts largely to a mapping of his critical comments about Catholicism and nonconformity, his sentimental ones about the Church of England, and his ambivalent, changing remarks about Jews (rather than about Judaism per se, about which he seems to have said nothing by this account). Looking for Orwell's views on nonJudaeo Christian faiths is to scrape the bottom of the admittedly extensive barrel of his occasional journalism. Brennan's methods and organisation are familar from the cannon of the Orwell literature-chapters based on the major works, the material amplified by an extensive reading of the journalism. 
Brennan's main assertions, which are bravely critical of the saint, are that for all his vaunted liberalism, he was unselfcritically prejudiced against Catholics throughout his life and that he shared conventional prejudices against Jews until it became apparent what was happening in Germany from the mid 1930s. He saw the Anglican church as mostly harmless, bad only when it got caught up with militaristic patriotism. It was part of the world which his alter ego George Bowling (Coming up for Air) had lost after the First World War with the advent of modernism. Brennan sees Orwell's anti-Catholicism and rather lazy antisemitism as directed at elite and the cosmopolitan stereotypes-these, like the unenthusiastic sympathy for Anglicanism and a dislike for the all too enthusiastic mode of nonconformists, were after all the unthinking prejudices of Orwell's class.

Does this add up to much and should it affect our reading of Orwell? We know that he was not an ethnographer. He was a political writer or, as Brennan demonstrates, a pamphleteer. The duty he felt to his subject matter was that of a humanitarian, democratic socialist. Orwell's representation of his subjects was selective in support of campaign against injustice, but, as was famously the case in The Road to Wigan Pier, he left a lot out if it did not support his argument. Brennan makes the point (more than once) that Orwell showed no interests in the real sociology of Catholicism in Britian between the wars and was unaware of or else ignored the sizeable and growing population of working class Catholics especially in the northwest. His targets remained the hierarchy, Catholic apologists like Belloc and Chesterton and, although with much more nuance, Catholic writers like Eveyn Waugh and Graham Green. Brennan argues that Orwell would have benefitted from studying the demographics, but is that the Orwell we want? In any case, we did not get it. Brennan also suggests that the polemical second part of The Road to Wigan Pier would have benefitted from severe editorial work by Gollancz, a point made by members of the 
Left Book Club when it was published. We would be less entertained and less likely to examine our own failings if that had been the case.

Brennan's challenge in making a book out of this is that Orwell did not participate in theological discourse per se and only treated religion directly in his early works and in the journalism. There is no serious, developing debate in Orwell's work about religion. By contrast, his engagement with the politics of the left and his changing perceptions of left intellectuals to deal honestly with totalitarianism constitutes a major theme. To write a book about Orwell in which this is taken as read and which looks to write about something else must have the air of Hamlet without the Prince. Nevertheless, Brennan succeeds in flagging up Orwell's continuing concern about the role of the church, and especially the Catholic church, in politics. He also reminds us, in tracing the genealogy of 1984, of the way the themes of religion and secularism were central to early $20^{\text {th }}$-century dystopian fiction, from H G Wells' A Modern Utopia (1905), through Zemyatin's We (1921) to Huxley's Brave New World (1932). For Orwell, uniforms, processions, orthodoxy, inquisitions, hierarchies and organisations with global aspirations, all of which he found in the Catholic Church, were tools of totalitarianism. The cult of Big Brother was at once both secular and religious, the antithesis of Orwell's humanitarian, socialist individualism, aiming to control the soul as well as the body. Brennan reminds us that there was more to Catholicism than this, and that Orwell's assertion that the individual's faith inevitably collapses under torture was an aspect of 1984 that was challenged by Christian readers.

Outside his discussion of Catholicism, Brennan has a fair amount to say about Orwell's writing about anti-semitism. Orwell became very interested in the social and political roots of anti-semitism and of racial prejudice more widely, but this was not fundamentally an exploration of religion and so at times sits uneasily in the book. If there is something which might have 
been developed at greater length, it is the relationship between Orwell and the English protestant tradition, both in its Puritan form and in the rational, anti-enthusiastic mode of eighteenth-century Anglicanism. The vicar from 150 years before that Orwell identified with most, if not the happiest one, was after all Swift.

\section{JEREMY CRUMP}

De Montfort University, UK 